\title{
Geometric and thermal evolution of a surge- type glacier in its quiescent state: Trapridge Glacier, Yukon Territory, Canada, 1969-89
}

\author{
Garry K. C. Clatrke and Erik W. Blake \\ Department of Geophysics and Astronomy, University of British Columbia, Vancouver, \\ British Columbia V6T 1W5, Canada
}

\begin{abstract}
Trapridge Glacier, Yukon Territory, Canada is a subpolar surge-type glacier. It last surged in the 1940s and is now in the late stages of quiescence. Since 1969, when the glacier was first surveyed, a large wave-like bulge has formed near the glacier terminus. Our surveys from 1969-89 show the profile evolution that has accompanied the formation and downflow propagation of this feature. Ice-temperature measurements taken in 1980-81 established that the bulge was forming at the boundary between thick warm-based ice lying up-glacier from the bulge, and thin cold-based ice lying down-glacier from it. The bulge is propagating at roughly $30 \mathrm{~m} \mathrm{a}^{-1}$ and thick ice has now completely overridden the region once covered by thin cold-based ice that we instrumented in 1980-81. In 1987, and again in 1988, the geographical positions of the 1980 measurement sites were redrilled and instrumented with new thermistor cables. Comparison of the 1980-81 data with that from 1987-88 shows that this region of the glacier has undergone a dramatic change in geometry and thermal regime. Water penetration into surface crevasses has warmed the 15 -m ice temperature by roughly $2^{\circ} \mathrm{C}$. The zone of transition from warm- to cold-based ice is migrating down-glacier but at a slower rate than that of the bulge feature. The transition from warm-based to cold-based ice appears to cause a discontinuity in the flow that resembles a transition from flow over a sliding boundary to flow over an adhering boundary. The discontinuity in the flow field is associated with anomalies in the temperature field and appears to be the source region for an englacial structure formed from subglacial sediment. This structure was not present in 1980-81 and is thought to have the geometry of a thrust fault or recumbent fold.
\end{abstract}

\section{INTRODUCTION}

Trapridge Glacier is a small sub-polar glacier situated in the St. Elias Mountains, Yukon Territory, Canada (Fig. 1). The glacier was identified as surge-type by A.S. Post and since 1969 has been the object of on-going glaciological and geophysical studies. Of the few surgetype glaciers that have been closely studied, Trapridge Glacier has several notable attributes: (1) It is small (length $\approx 4 \mathrm{~km}$ ) and comparatively thin (depth $\approx 80 \mathrm{~m}$ ), making it tractable for detailed scientific study. (2) Its subpolar, rather than temperate, thermal regime is characteristic of a large class of surge-type glaciers found in northwestern Canada, Arctic Canada, interior Alaska, East Greenland and Spitsbergen. Moreover, the thermal structure of Trapridge Glacier has affinities with that of past and present continental ice sheets; warm-based ice is bounded by a margin of cold-based ice that affects both ice dynamics and subglacial water flow. (3) The glacier is known to rest on a deforming sediment substrate (Blake and Clarke, 1989; Blake and others, in press). Subglacial processes that we observe beneath Trapridge Glacier may therefore have direct relevance to the mechanics of West Antarctic ice streams such as Ice Stream B which also rest on deforming sediment.

The long-term objective of our program on Trapridge Glacier is to comprehend the mechanism of glacier surging. Despite the impressive legacy from the study of Variegated Glacier and its 1982-83 surge (e.g. Bindschadler and others, 1977; Kamb and others, 1985; Humphrey and others, 1986; Raymond and Malone, 1986; Kamb, 1987; Kamb and Engelhardt, 1987; Raymond and Harrison, 


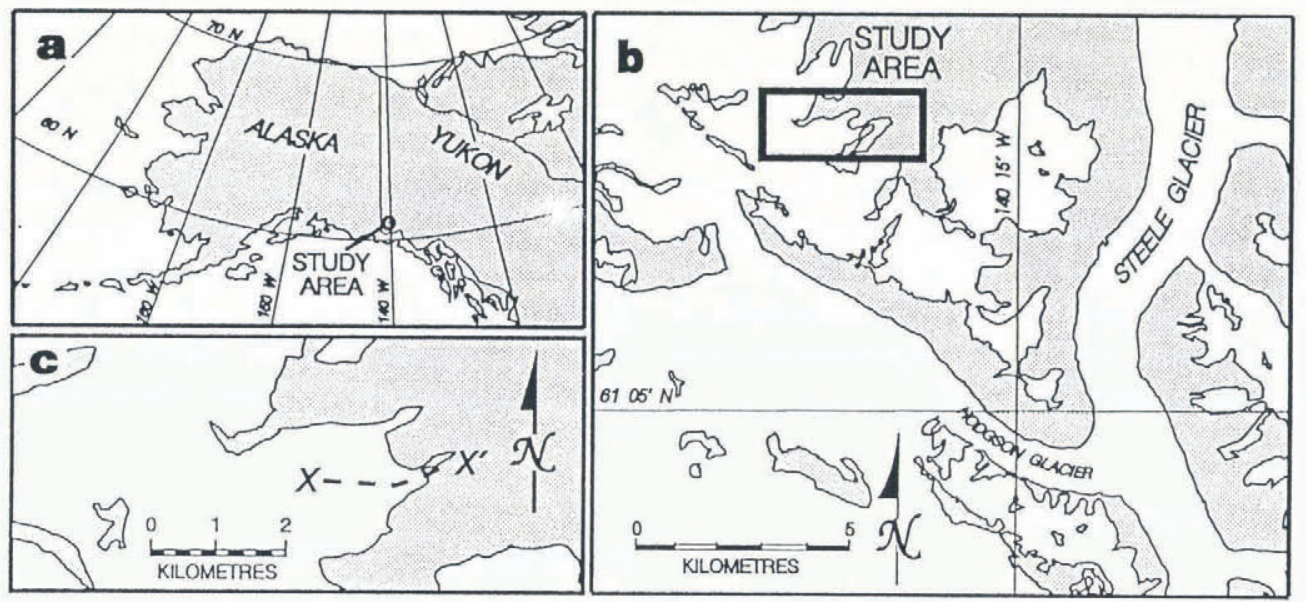

Fig. 1. Trapridge Glacier study area. (a) Location of study area in western Yukon Territory, Canada. (b) Location of Trapridge Glacier study area within the Steele Creek drainage basin. (c) Outline map of Trapridge Glacier and environs based on 1981 photogrammetric mapping. The approximate location of the centre-line profile is indicated by a dashed line labelled $X-X^{\prime}$.

1988), the question of surge mechanism remains contentious. The emphasis of our field study is on the role of subglacial deformation and hydrological processes in triggering and maintaining a surge (Clarke, 1987; Blake and Clarke, 1988, 1989; Smart and Clarke, 1988; Clarke and Gérin, 1989; Stone and Clarke, 1989; Clarke and Blake, 1990; Blake and others, in press). In addition to
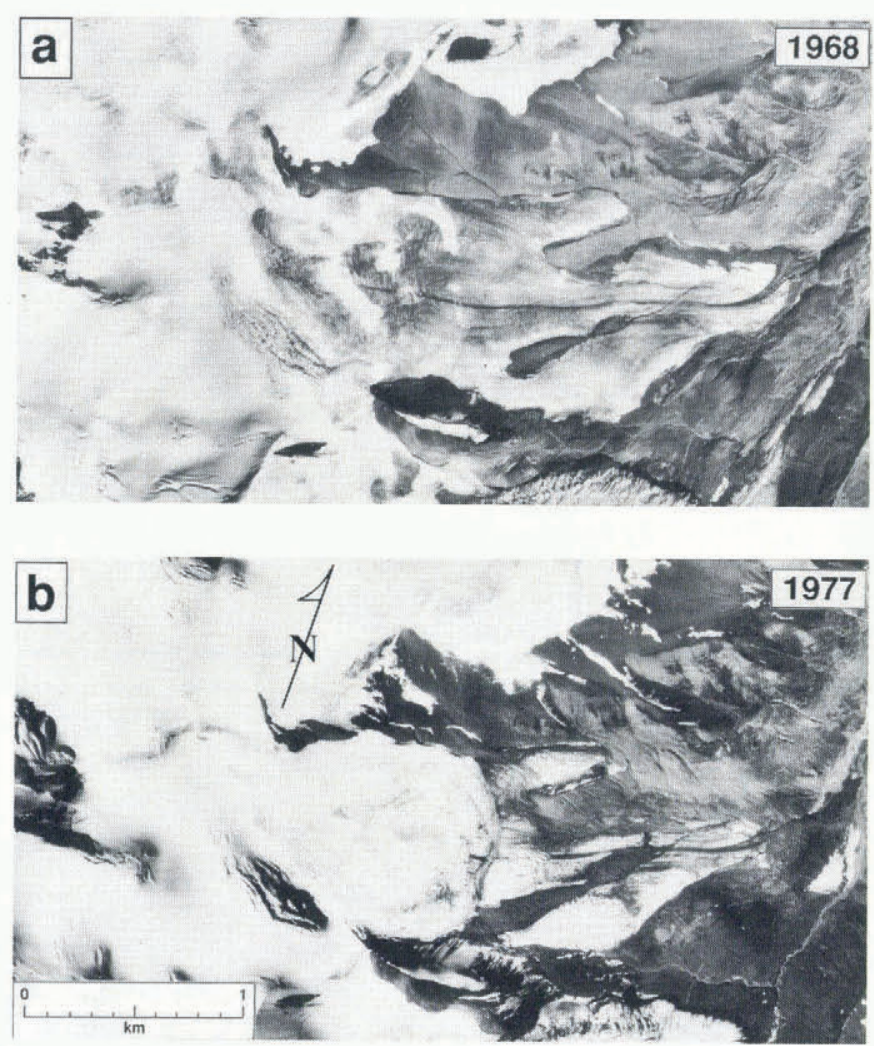

Fig. 2. Evolution of Trapridge Glacier during its quiescent phase. Note the progressive deglaciation of the lower reaches of the glacier and the growth of a wave-like bulge in the area of active ice. (a) Vertical aerial photograph of Trapridge Glacier on 15 August 1968. (Part of Canadian Government photograph A20128-29.) (b) Vertical aerial photograph of Trapridge Glacier on 4 August 1977. (Part of Canadian Government photograph A24762-131.) focused investigations aimed at identifying and quantifying subglacial physical processes, we continue a broad-scale characterization of the geometry, flow and temperature fields. The purpose of the present paper is to report on the dramatic changes in geometry and thermal structure that have occurred during our study of the glacier. These largescale changes have resulted from a gradual and continuous evolution of the glacier rather than from a series of recognizable events such as surge pulses. Comparison of vertical aerial photographs from 1968 and 1977 (Fig. 2) shows the prevailing trends during the quiescent period from 1968 to the present. There has been progressive deglaciation of the surge "receiving area" (Meier and Post, 1969) that had been covered by ice during the previous surge. Concurrent recharging of the "reservoir area" has

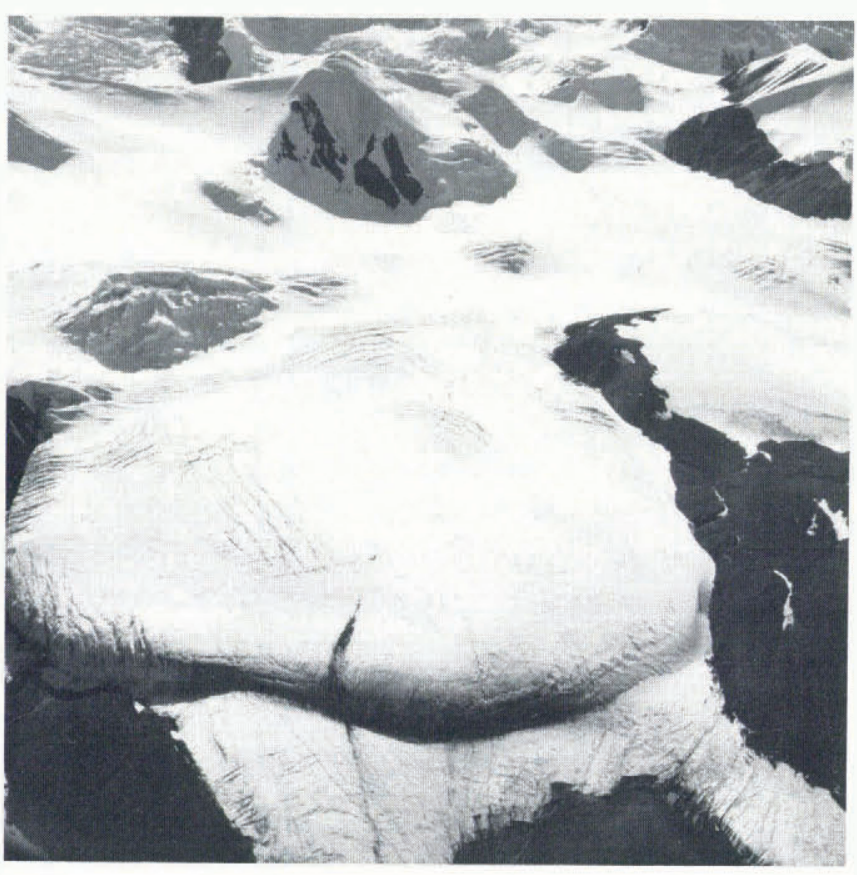

Fig. 3. Oblique photograph showing the wave-like bulge on Trapridge Glacier (24 June 1980). The photograph is by G.K.C.C. and reproduced with permission of the Canadian Journal of Earth Sciences. 
resulted in the formation of a large wave-like bulge that marks the boundary between reservoir and receiving areas (Fig. 3). The development of such bulges seems to be a common feature of sub-polar surge-type glaciers as they approach the active phase of the surge cycle. Our study reveals that the formation of the Trapridge Glacier bulge is intimately related to the glacier thermal regime. This interplay between thermal structure and flow dynamics is one of the most fascinating aspects of the geometrical and thermal changes that we have observed.

\section{HISTORICAL BACKGROUND}

Scientific expeditions organized by W. A. Wood from 1935 to 1941 (Wood, 1936, 1942; Wood, 1940; Sharp, 1947, 1951) establish what little is known about Trapridge Glacier prior to its most recent surge around 1945. R.P. Sharp, the 1941 expedition geologist, described "Glacier 13" (Trapridge Glacier) as "advancing rapidly"; an accompanying photograph shows that the glacier had developed a vertical ice front that appears to be advancing over inactive ice down-flow from the ice cliff (Sharp, 1947, fig. 5). It is tempting to believe that Sharp was observing Trapridge Glacier during a surge, but the present appearance of the glacier closely resembles that in a 1941 photograph (Sharp, 1951, plate 5B), and no surge is currently in progress. World War II interrupted Sharp's field work and there is an observational hiatus from fall 1941 to summer 1951 when a Canadian Government aerial photogrammetric survey was completed. During this hiatus, the photographic record clearly reveals that a major surge had taken place (Clarke and others, 1984, fig. 3).

\section{PROFILE EVOLUTION}

Quantitative study of Trapridge Glacier began in 1969 with the surveys of Collins (1972). A network of flow markers, installed in the summer of 1969, has been enlarged and repeatedly surveyed to yield information on changes in surface geometry and flow rate from 1969 to 1989. The 1969-70 surveys of Trapridge Glacier revealed the existence of a zone of strongly emergent flow resulting from the collision between active and immobile ice near
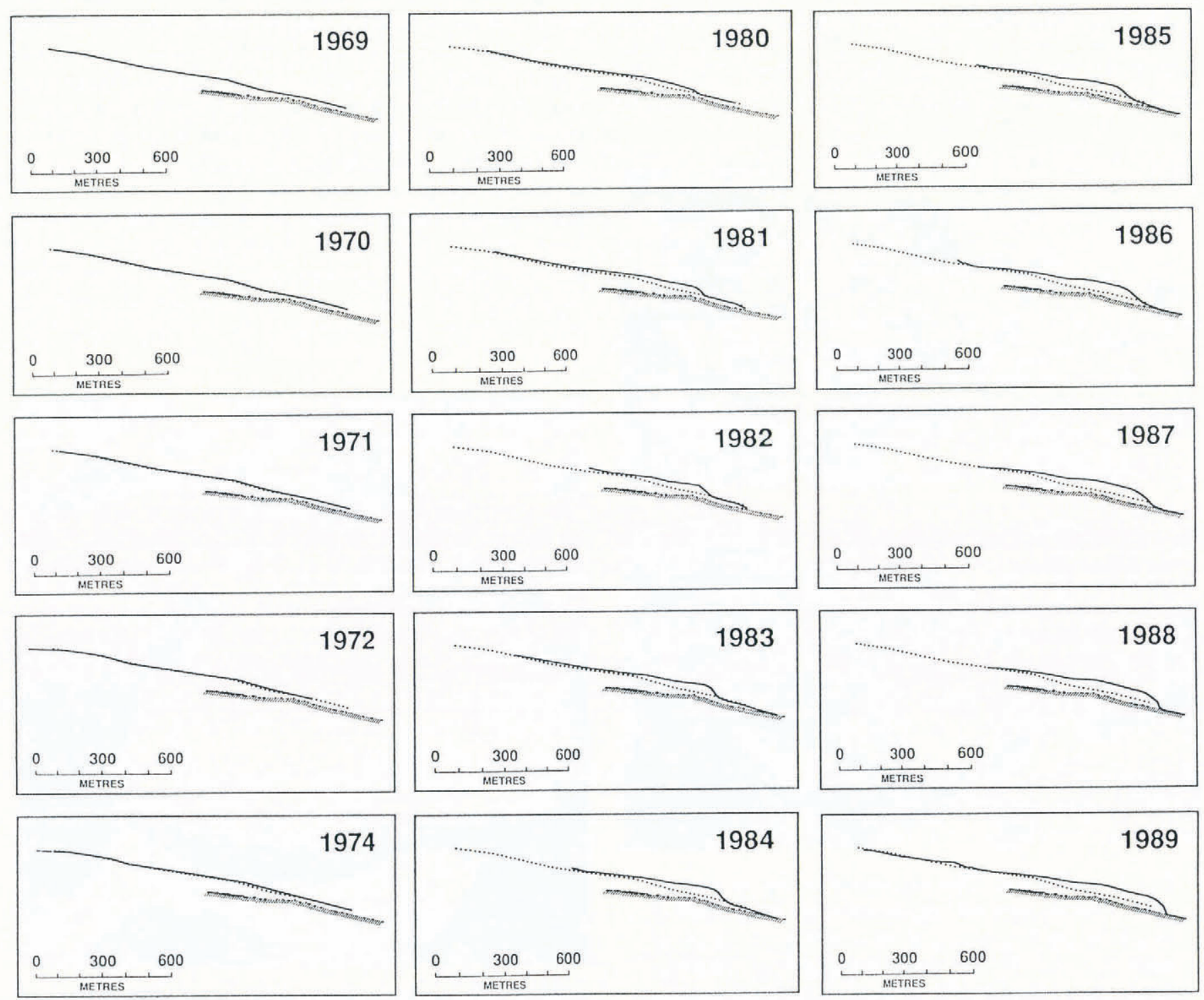

Fig. 4. Evolution of Trapridge Glacier surface profile, 1969-89. The 1969 profile is taken as a reference (dotted line) against which the profile in subsequent years can be compared. Hatched lines indicate the profile of the glacier bed as determined by ice drilling. Vertical and horizontal scales are identical. 
the lower terminus. This led Collins to refer to the stagnant lower tongue as an ice "dam", although at the time of his proposal the morphological consequences of the dam were barely evident. From 1969-80 this collision zone evolved into a wave-like bulge that is the most striking feature of the present glacier (Fig. 3).

Figure 4 shows the evolution of the glacier surface profile from 1969-89. The 1969 profile (dotted line) is taken as a reference against which subsequent profiles are compared. The elevation profile of the glacier bed (hatched lines) has been determined using results from extensive thermal drilling to the glacier bed. Over the period 1980-89, more than 270 holes were drilled to the glacier bed and the easting, northing and elevation coordinates of the surface position of each hole were measured at the time of drilling. Subtraction of the measured hole length from the surface elevation gives the elevation of the bed surface, if errors caused by nonverticality of the holes are neglected. These determinations of bed topography were placed in a computer data base and subsequently retrieved to yield bed-elevation profiles. What is noteworthy in Figure 4 is the magnitude of the geometric changes that have taken place since 1969. The 1969-70 changes were small but entirely consistent with the subsequent growth of a wave-like bulge. Although the flow effects of immobile ice were apparent to Collins in 1970, the profile evolution from 1969-74 was sufficiently subtle that it escaped notice by those working on the glacier surface. No field observations were conducted in 1973 and from 1975-79. By the summer of 1980, the glacier surface had undergone an impressive transformation and the wave-like bulge was well developed (Fig. 3).

From 1969-80, bulge formation was the dominant process controlling profile evolution, and from 1980-89 bulge propagation was dominant. Figure 5 shows details of the bulge propagation from 1980-89. The 1980 profile is plotted as a solid line and annual profiles thereafter are plotted as dotted or dashed lines. Throughout this phase, the profile has progressively steepened and is propagating down-flow at a fairly constant rate averaging roughly $30 \mathrm{~m} \mathrm{a}^{-1}$.

From 1980-88, the bulge existed at the boundary between actively flowing ice and a thinning region of inactive ice downstream from the bulge that we refer to as the "apron" (Figs 3 and 5). In 1989, advancing ice had completely overridden this apron, and it is now evident

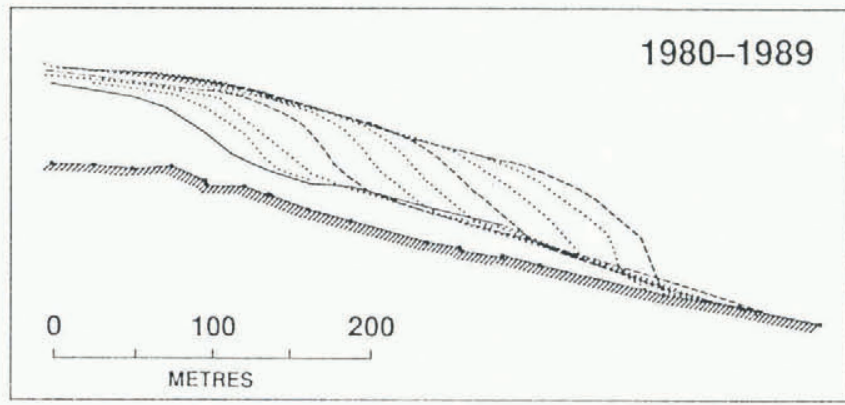

Fig. 5. Propagation of wave-like bulge, 1980-89. The 1980 bulge profile is plotted as a solid line. Profiles for subsequent years are plotted as dashed lines (1983, 1986 and 1989) or dotted lines (all other years). Hatched lines indicate the glacier-bed profile as determined by ice drilling. Vertical and horizontal scales are identical.
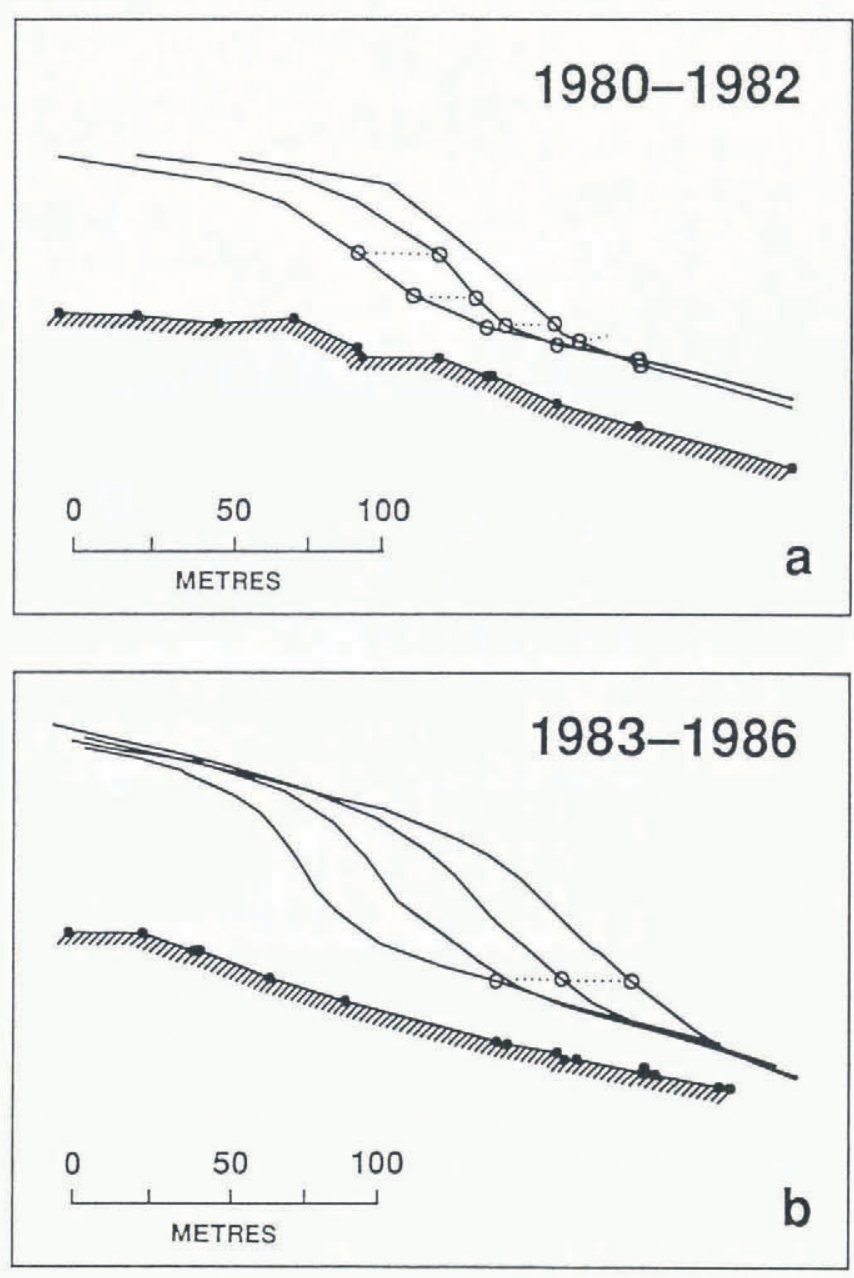

Fig. 6. The activation of stagnant frontal apron down-flow from the advancing wave-like bulge. The locations of survey markers are indicated by open circles and the year-to-year flow trajectories of these markers are indicated by dotted lines. The invariable tendency is for apron ice to be longitudinally compressed and continuously incorporated into the advancing bulge. There is no evidence of markers on the apron being overridden by thrust-faulted ice. Solid lines denote the surface profile at annual intervals; hatched lines denote the glacier-bed profile as determined by ice drilling. Vertical and horizontal scales are identical. (a) 1980-82. (b) 1983-86.

that the presence of the apron was necessary for preventing the formation of an ice cliff. Activation and incorporation of apron ice into the advancing bulge front is accomplished, at least in its visible manifestations, by creep rather than by shear faulting (Fig. 6). Longitudinal compression of ice immediately down-slope from the bulge causes the ice surface to rise, allowing the bulge profile to propagate in a continuous manner (Fig. 7). In the collision zone, between thick active ice and thin stagnant ice, it might be expected that shear failure would occur and that the active ice would override the inactive ice. We have found no surface evidence for this style of fault-like deformation at the boundary between the bulge and the apron. Thrust faults, if they are present, do not intersect the glacier surface.

\section{EVOLUTION OF THERMAL STRUGTURE}

The thermal structure of Trapridge Glacier has been 


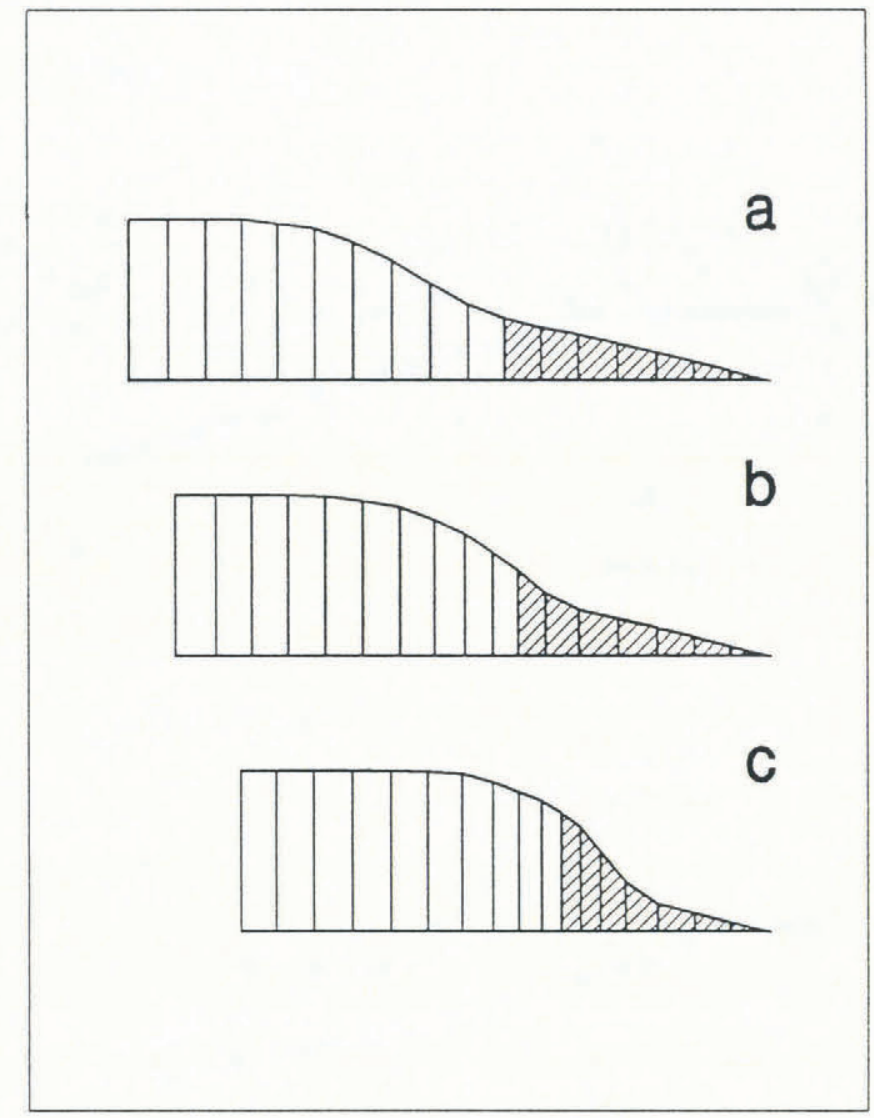

Fig. 7. Schematic diagram showing incorporation of the stagnant frontal apron into the bulge. Viewed from the apron, the developing structure has the appearance of a thrustgenerated feature, but it is actually generated by continuous deformation as the advancing bulge mobilizes stagnant ice from the apron. studied more closely than that of any other mass of glacier ice in the world. This research began in 1972 (Jarvis and Clarke, 1975) and has continued to 1989. Over this interval, 54 holes have been instrumented with thermistor cables. The 1972 holes were drilled using electrothermal probes and few, if any, of these holes are believed to have reached the glacier bed. Subsequent drilling, begun in 1980, has been done using a hot-water jet and most of these holes are known to have reached the bed. The 1972 program revealed the existence of the "cold ring" thermal regime, characteristic of ice caps in Nordaustlandet (Schytt, 1969). At the time of this discovery we believed that this was evidence for some form of thermal mechanism controlling glacier surging (Jarvis and Clarke, 1975; Clarke, 1976; Clarke and others, 1977). We no longer subscribe to this idea although, for sub-polar glaciers such as Trapridge Glacier, the thermal regime may have some influence on the processes that conspire to produce surges. The most significant result from our study of thermal structure was that the formation and propagation of the bulge are strongly related to the thermal structure.

The 1980-81 program of drilling and ice-temperature measurement revealed the relationship between flow, geometry and thermal structure of the glacier (Fig. 8). Down-flow from the bulge, ice is thin, inactive and coldbased; up-flow it is thick, flowing at roughly $25 \mathrm{~m} \mathrm{a}^{-1}$ and warm-based. The collision zone is located at the boundary between unfrozen bed, over which sliding is possible, and frozen bed, over which sliding is inhibited. The cold-based frontal apron acts as a mechanical dam that causes the glacier to thicken up-flow from it. This thickening cannot continue indefinitely because apron ice is progressively thinning by surface ablation and because, upstream from
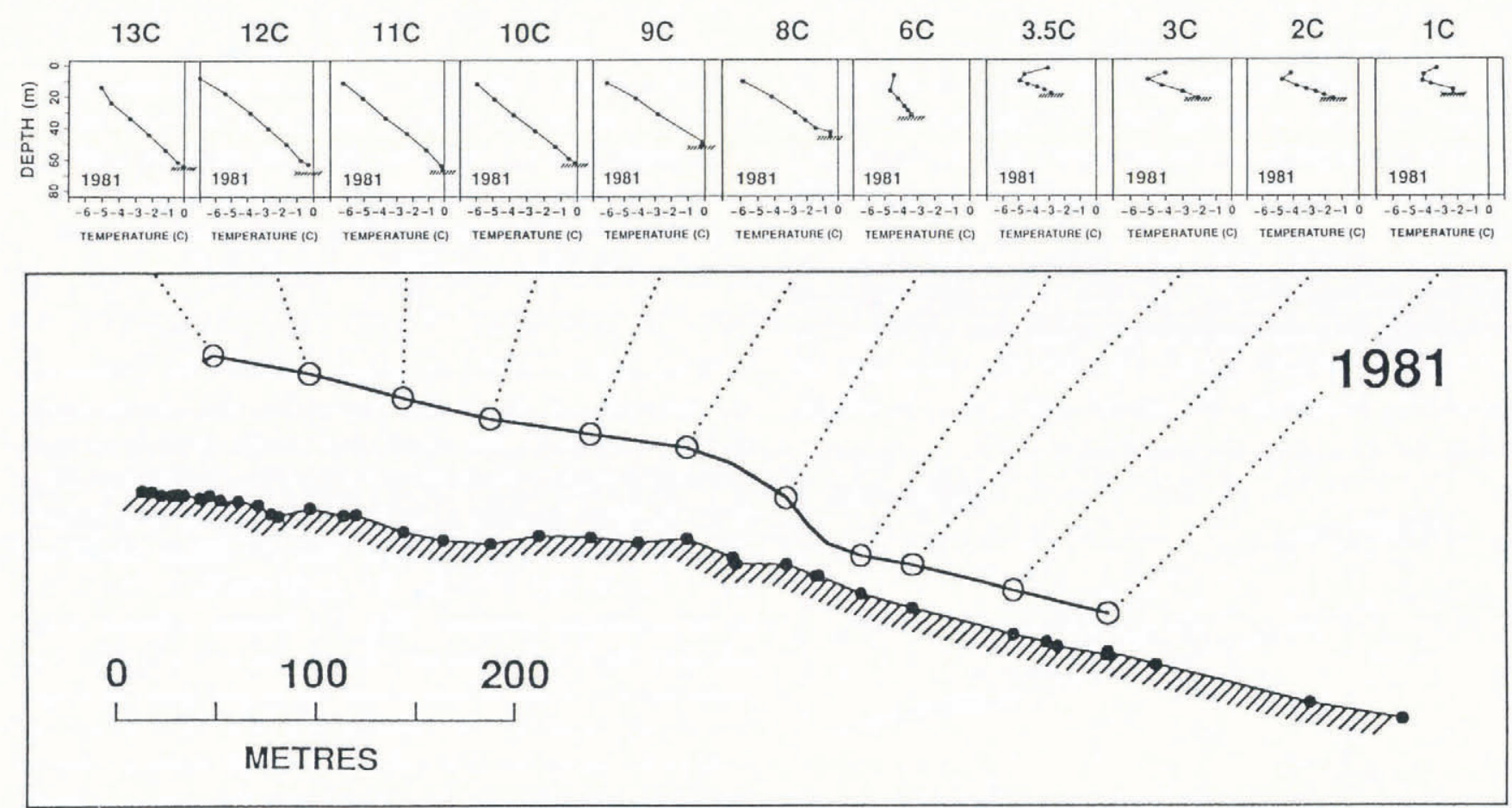

Fig. 8. Thermal structure of Trapridge Glacier in 1981. The profile plot shows the 1981 site locations (open circles), surface profile (solid line) and bed profile (hatched line). Solid circles along the bed profile indicate spot measurements of bed elevation as determined by drilling. Vertical and horizontal scales are identical. Inset graphs show the results of ice-temperature measurements at sites along the centre-line profile (denoted 13C, 12C, etc.). Drilling depths for each of these measurement sites are indicated by hatched horizontal lines. Dotted lines connect site locations to the appropriate inset graph. 
the effective dam, increasing ice thickness and surface slope in the collision region raise the stress level. One can foresee several possible outcomes: (1) Stress rises to a level that enables creep processes to become vigorous and propagate the bulge front down-glacier. (2) Stress rises to a level that causes faulting to occur at the warm-cold transition and the bulge advances by overthrusting. (3) Stress rises to a level that causes faulting to occur at the boundary between thin ice, comprising the apron, and thick ice, comprising the bulge front; the bulge advances by overthrusting. (4) The onset of thermal instability at the warm-cold transition allows the warm-cold boundary to migrate down-flow enabling the bulge to propagate by bottom sliding. (5) Subglacial hydrological processes allow water to flow into the cold-based region thereby propagating the warm-cold transition down-flow and allowing the bulge to propagate by bottom sliding. Our observations suggest that items (1) and (2) are the dominant mechanisms by which the bulge profile is advanced.

Ice deformation eventually severs thermistor cables so that most of the holes instrumented in 1980 (Fig. 9) had to be redrilled and re-instrumented in 1981 (Fig. 8). In addition, the observation line was extended up-glacier (adding holes at 12C and 13C) and down-glacier (adding 1C). Site 4C, which was was engulfed by the advancing bulge, was replaced by site $3.5 \mathrm{C}$ immediately down-flow
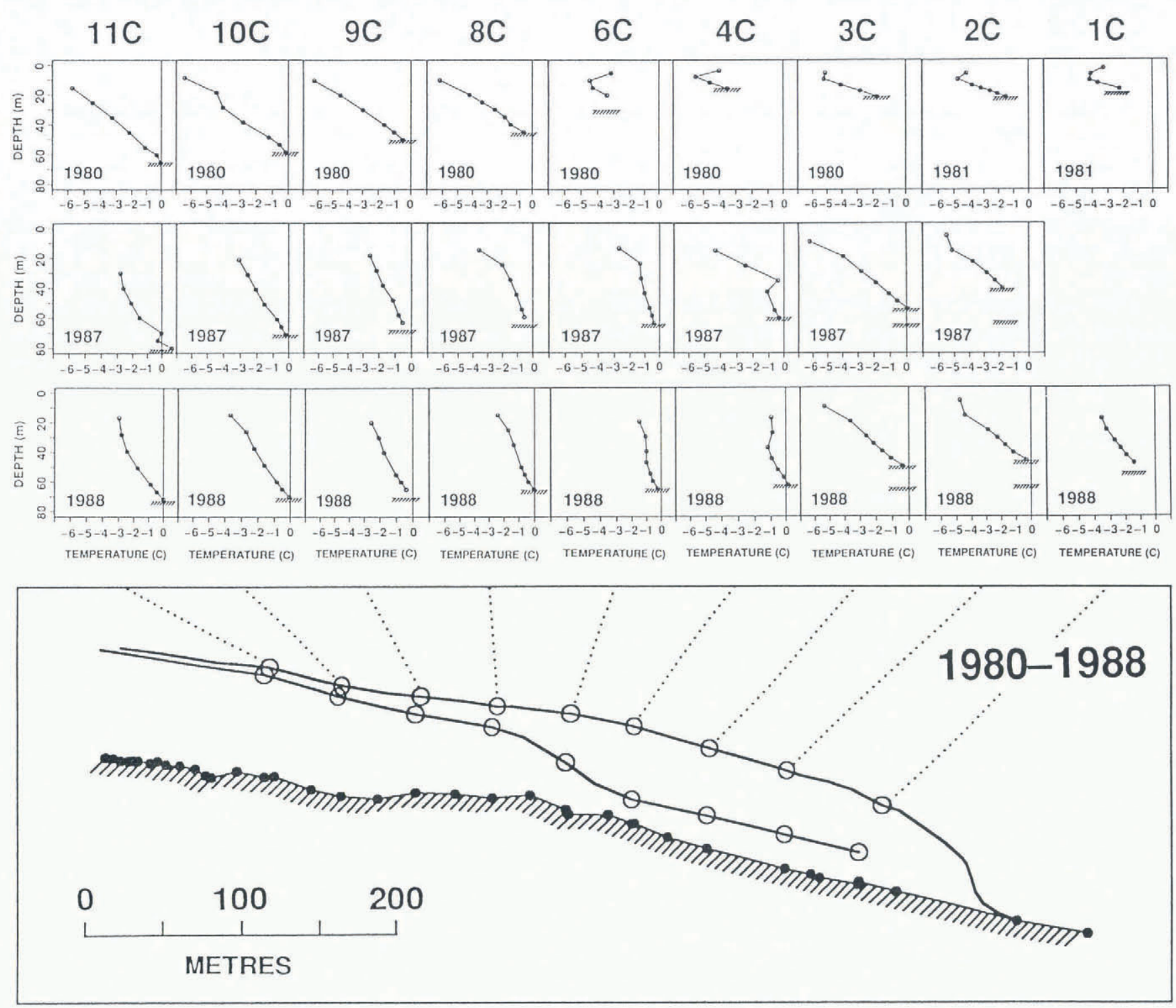

Fig. 9. Thermal structure of Trapridge Glacier in 1980,1987 and 1988. The profile plot shows the 1980 and 1988 site locations (open circles), surface profiles (solid lines) and bed profile (hatched line). Solid circles along the bed profile indicate spot measurements of bed elevation as determined by drilling. Vertical and horizontal scales are identical. Inset graphs show the results of ice-temperature measurements at sites along the centre-line profile (denoted 13C, 12C, etc.) in various years. Drilling depths for each of these measurement sites are indicated by hatched horizontal lines. Dotted lines connect site locations to the appropriate set of inset graphs. Note that 1981 measurements have been included to extend the spatial coverage of the 1980 ice-temperature measurements. This substitution is justified because sites undisturbed by the advancing bulge show little year-to-year variation. Note also the 1987 and 1988 insets for sites 3C and $2 C$ show two hatched horizons. The uppermost horizons are respectively determined from 1987 and 1988 drilling depths; the lowermost horizons are from 1980-81 drilling depths. The depth discrepancies arise because of the presence of an internal sediment structure. 
from the bulge front. Holes drilled in 1981 were located at the same surface markers that identified the 1980 drill holes. Thus, for example, the hole drilled at site 9C(1980) (i.e. the summer 1980 location of surface marker pole $9 \mathrm{C}$ ) was redrilled at $9 \mathrm{C}(1981)$ (the summer 1981 location of marker $9 \mathrm{C})$. Our temperature measurements were therefore taken at fixed locations within a moving coordinate system that can be regarded as analogous to the Lagrangian coordinate system used in continuum mechanics. Figure 8 shows the 1981 geometry of the bulge region and the associated temperature measurements. Note that up-flow from the bulge (sites 13C, 12C, 11C, 10C and 9C) bottom temperature is at the melting point, whereas on the bulge and down-flow from it (sites $6 \mathrm{C}, 3.5 \mathrm{C}, 3 \mathrm{C}, 2 \mathrm{C}$ and 1C) bottom temperature is well below the melting temperature, ranging from $-3.4^{\circ} \mathrm{C}$ at site $6 \mathrm{C}$ to $-1.5^{\circ} \mathrm{C}$ at site $2 \mathrm{C}$. The $15 \mathrm{~m}$ ice temperature also varies along the profile ranging from $-5.9^{\circ} \mathrm{C}$ at site $12 \mathrm{C}$ to $-3.0^{\circ} \mathrm{C}$ at site 2C. The reversed temperature gradients (i.e. temperature increasing with distance from the bed) apparent at sites $6 \mathrm{C}, 3.5 \mathrm{C}, 2 \mathrm{C}$ and $1 \mathrm{C}$ are a consequence of summer warming of the ice surface and are within the near-surface zone disturbed by the annual temperature cycle. Thus temperatures measured in the uppermost $10 \mathrm{~m}$ should be ignored.

Although the 1980-81 ice-temperature measurements revealed the thermal structure of Trapridge Glacier, the observation interval was too short to reveal the time evolution of thermal structure. We therefore repeated our program of drilling and ice-temperature measurements in 1987 and again in 1988. For these measurements we attempted to place our holes at the geographical positions of the 1980 holes. Our measurement coordinate system for the 1980, 1987 and 1988 data therefore resembles the Eulerian (spatially fixed) coordinate system of continuum mechanics. Of course, a true Eulerian configuration is impossible to achieve because, once emplaced, the thermistor cables are transported with the ice and cannot maintain a fixed geographical position.

From 1980-89 the bulge advanced roughly $285 \mathrm{~m}$ and in doing so has completely overridden the region once covered by the frontal apron of thin, stagnant, cold-based ice. By redrilling and re-instrumenting holes at the 1980 thermistor cable sites we have determined how the changing glacier geometry has affected the thermal structure and have also examined the migration of the warm- to cold-based transition. In comparing the 1980 temperature measurements with those taken in 1987 and 1988, striking differences are apparent (Fig. 9). Ice temperature at a depth of $15 \mathrm{~m}$ has warmed by a typical value of $2^{\circ} \mathrm{C}$. We attribute this temperature increase to water penetration into crevasses that have grown deeper and more numerous since 1980 .

A second noteworthy change is the increase in deep ice temperature at sites that in 1980 were cold-based (4C, 3C, 2C, $1 \mathrm{C}$ in Figure 9). In 1980 the transition from warm- to cold-based ice was located near $8 \mathrm{C}$ and by 1988 it had migrated at least as far down-flow as site $4 \mathrm{C}$. This increase in deep ice temperature has not, we believe, been accompanied by the formation of a layer of temperate basal ice as exists, for example, in polythermal glaciers such as White Glacier (Blatter, 1987; Hutter and others, 1988). Comparison of 1980-81 measurements from sites $3 \mathrm{C}$ and
2C with 1987-88 data from the same geographical positions reveals an extraordinary discrepancy between the expected and actual drilling depths. Our interpretation, justified in a subsequent section, is that an englacial structure, composed of subglacial sediment, formed beneath these sites. In Figure 9 the 1987 and 1988 insets for sites $3 \mathrm{C}$ and $2 \mathrm{C}$ show two bed horizons. The uppermost horizon marks the drilling depths of 1987-88 holes and the lowermost horizon marks the level of the 1980-81 glacier bed. There are no measurements of ice temperature in the zone between these two horizons but we surmise that basal temperature remains below the melting temperature. It is interesting that the 1988 ice temperature indicated by the lowermost thermistors at sites $3 \mathrm{C}$ and $2 \mathrm{C}$ is within $0.3^{\circ} \mathrm{C}$ of the melting temperature despite the fact that the true glacier bed lies roughly $15 \mathrm{~m}$ below the level of these thermistors. At warm-bedded sites farther up-glacier (Figure 9, insets for 1988 sites 11C, 10C, 9C, 8C, 6C and 4C) the ice temperature $15 \mathrm{~m}$ above the bed is substantially colder, varying from $-0.8^{\circ}$ to $-1.1^{\circ} \mathrm{C}$. We believe that the explanation of the warm deep ice at $3 \mathrm{C}$ and $2 \mathrm{C}$ is that wet subglacial sediment has been transported from the warmbased zone to construct the internal feature. The 1987 and 1988 temperature profiles at site 4C (Fig. 9) are anomalous in that they reveal a zone of decreasing temperature with depth. In the absence of an internal heat source, such a feature must be transient. It is a reasonable conjecture that the disturbed temperatures are in some way associated with the deformation that produced the internal structure beneath sites $3 \mathrm{C}$ and $2 \mathrm{C}$. Apparent reversed temperature gradients can also result if thermistor cables are incorrectly wired or measurements are incorrectly taken, but neither possibility can explain the temperature anomaly at site 4C. The anomaly observed in 1987 is similar to that observed in 1988 but the measurements were taken on two different thermistor cables installed in two different holes. Between the time of drilling and the time of final temperature measurement, many separate sets of temperature measurements were taken so that the approach to thermal equilibrium was closely monitored.

Figure 10 unifies the results of our study of geometry, thermal structure and flow for the years 1980, 1981, 1987 and 1988. Obvious qualitative features of the evolution from 1980-88 are pronounced warming of the upper $30 \mathrm{~m}$ of the glacier and the complexity of the 1987-88 thermal structure compared to that in 1980-81. The location of the postulated internal structure is indicated by a dashed horizon in the 1987 and 1988 cross-sections (Fig. 10c and d). The temperature anomaly at site $4 \mathrm{C}$ leads to overturning of the $-1^{\circ} \mathrm{C}$ isotherm. Arrows show the direction and magnitude of the surface flow vectors.

Certain inconsistencies in the data used to generate Figures 8, 9 and 10 must be acknowledged. Thermal drilling disturbs ice temperature and the time for such disturbances to become negligible depends on hole radius, ambient temperature of the surrounding ice and other factors. Thus, deep thermistors installed in warm ice, for example that near the glacier bed, take far longer to reach equilibrium than thermistors installed in cold ice. Another source of difficulty is that the interval between installation of thermistor cables and the taking of final temperature measurements differs from site to site because holes were not simultaneously drilled and because thermistor long- 

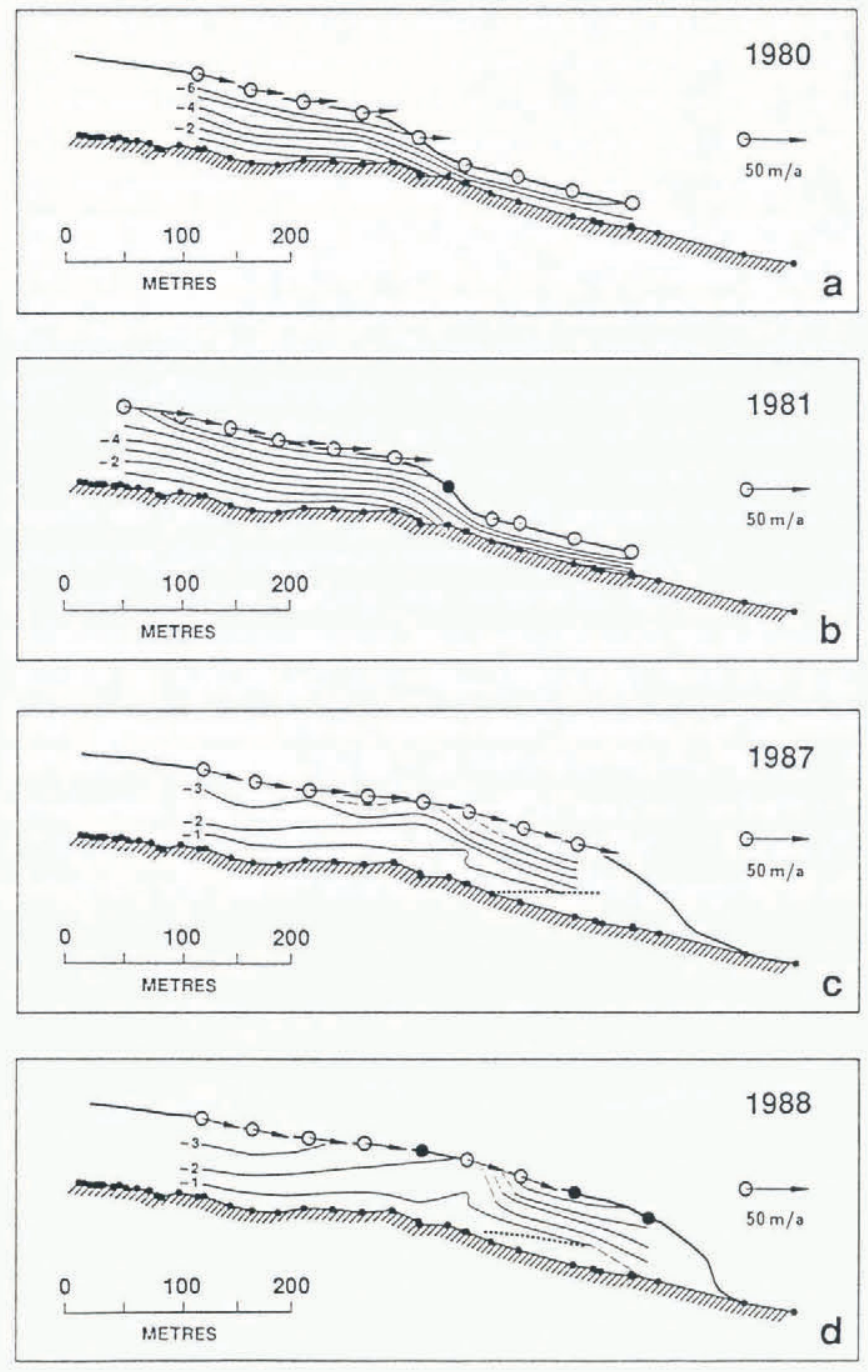

Fig. 10. Evolution of the geometry, flow and thermal structure structure of Trapridge Glacier, 1980-88. Surface-profile markers are indicate by large open or solid circles; depth control points along the bed profile (hatched line) are indicated by small closed circles. Horizontal and vertical scales are identical. Ice temperature is contoured at an interval of $1^{\circ} \mathrm{C}$; dashed contours indicate regions where contours are poorly controlled. Arrows radiating from open circles indicate the magnitude and direction of surface-flow velocity; open circles without arrows are associated with neglible flow rates; solid circles denote data gaps resulting from melted-out marker poles.

evity is variable. Bottommost thermistors and all thermistors on cables installed close to the bulge front were especially short-lived. We decided against attempting to correct temperature measurements to their equilibrium values because we feared the correction would introduce a new source of uncertainty. Minor inconsistencies between data from 1980 and 1981 and between 1987 and 1988 result from the foregoing difficulties and are not a cause for concern.

The 1981-82 program generated an erroneous conclusion that we now wish to emend. Comparison of the measured 1981 and 1982 near-basal ice temperatures in the cold-based stagnant ice zone indicated that nearbasal ice in this region had undergone a warming of up to $0.5^{\circ} \mathrm{C}$ from 27 September 1981 to 11 August 1982 (Clarke and others, 1984, fig. 6). Basal temperature increases having similar character were never again observed and we now suspect that the supposed increases resulted from a methodological error. On numerous occasions we have observed that measurements of the resistance of englacial thermistors are corrupted by the presence of an unexplained voltage source. We believe that this results from some sort of electrochemical phenomenon related to wire corrosion or to some other source of ionic impurities in ice near the thermistor but we have not succeeded in identifying the precise mechanism. The effect of this electrochemical potential is to place a small battery in series with each thermistor. These unusual potentials have a measured magnitude that is strongly dependent on the input impedance of the measuring device, indicating that the ostensible battery is a poor current source. The magnitude of the disturbing potential decays with time and our usual approach to removing its influence is to wait for the measured resistance value to stabilize then reverse the electrical contacts and remeasure the resistance. The average value of the "forward" and "reverse" resistances is taken as the true resistance. The 1982 observations, upon which we based the conjecture of a subglacial thermal energy source, were based on a single set of measurements taken by an observer who was incompletely familiar with this problem of electro-chemical voltages.

In 1983 we drilled 12 holes in the cold-based "apron" ice down-flow from the bulge front to seek fluctuations in basal ice temperature that might indicate water flowing beneath the cold-based bed or in short-lived cold-walled channels passing through the ice. We reasoned that deep ice-temperature measurements might be used to identify and locate subglacial water routes if they existed. Measurements at these sites were continued for several years until the locations were overridden by the advancing bulge. The longest surviving sites yielded bottom-temperature records that extend from 1983 to 1985 . We found no further evidence for subglacially generated temperature fluctuations and found no thermal evidence for localized water flow in channels at or beneath the bed.

\section{GENERATION OF INTERNAL STRUCTURE}

Drilling and ice-temperature measurements in 1987 and 1988 point strongly to the presence of an internal sediment structure that did not exist at the time of the 1980 and 1981 drilling and ice-temperature measurements. Holes drilled in 1987 and 1988 at sites $3 \mathrm{C}(1980)$ and $2 \mathrm{C}(1980)$ were stopped by a sediment horizon that had not been encountered in 1980 and 1981. Samples taken from the bottom of the 1988 drill holes (Fig. 11) confirm that the hot-water drill intersected a sediment horizon and that the sediment was identical in character to samples taken from holes that are known to have reached the bed. The roundness and striations of individual clasts indicate that the sediment is of subglacial origin rather than supraglacial or englacial moraine which is characteristically angular. Our "Hoover" sampler sucks loose material from the bed and tends to undersample the very fine- and very coarsegrained constituents so we did not examine the quantitative granulometry of the samples. The fact that four independent holes drilled in 1987-88 all failed to reach the 

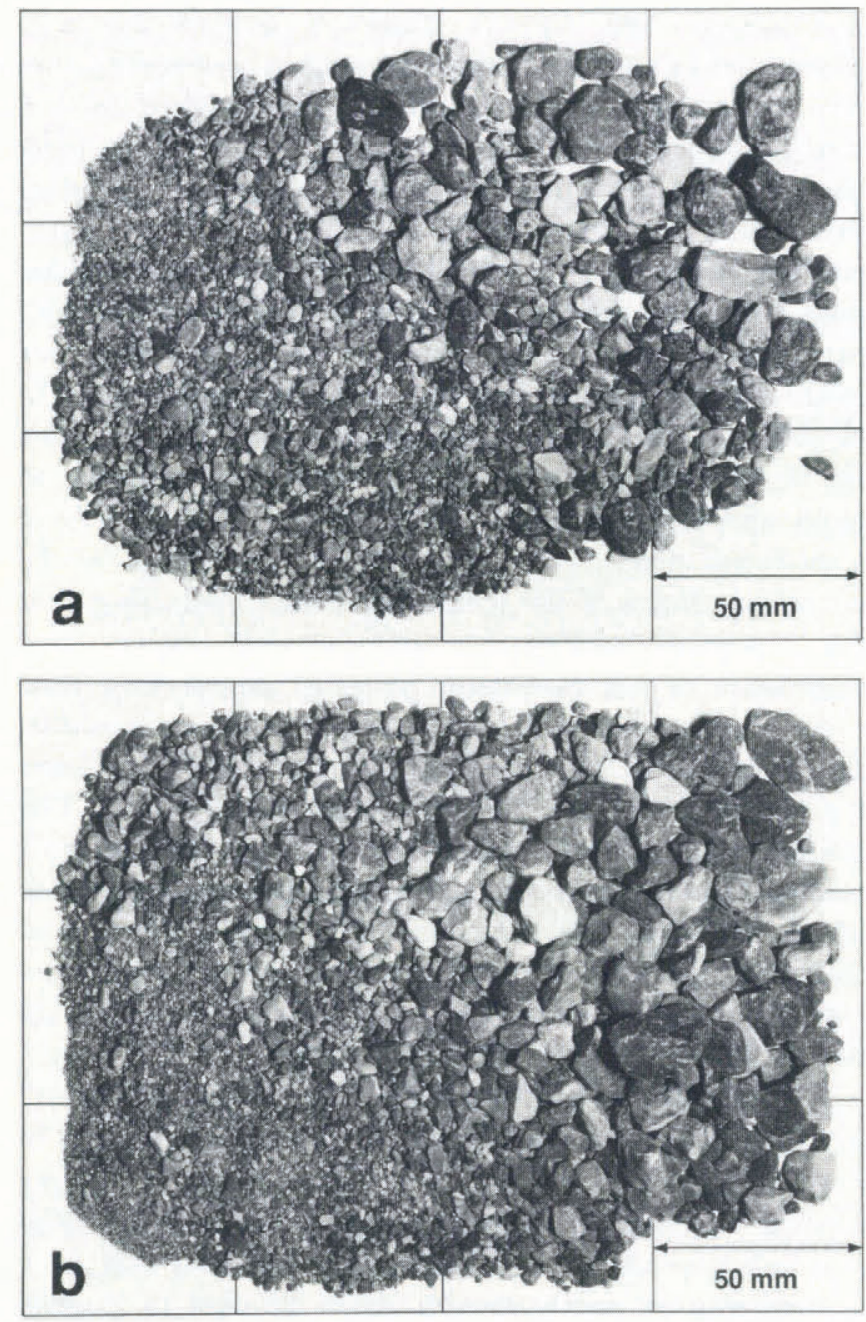

Fig. 11. Basal sediment extracted by "Hoover" sampling of 1988 drill holes. These holes did not penetrate to the glacier bed but intersected an internal feature constructed from subglacial sediment. Note the range of sizes and the roundness of clasts. Samples have been placed on a $50 \mathrm{~mm} \times 50 \mathrm{~mm}$ grid. (a) Sediment sample $88 H V 46$ retrieved from the bottom of 1988 hole drilled at site $3 C(1980)$. (b) Sediment sample $88 \mathrm{HV} 47$ retrieved from the bottom of 1988 hole drilled at site 2C(1980).

level of the 1980-81 glacier bed in the same region suggests that the sediment structure is spatially continuous over a considerable area. The cause for such a structure to form is most surely the transition from warm-based to cold-based ice that also gives rise to the disturbed thermal structure observed independently in 1987 and 1988 immediately upflow from the internal sediment structure (refer to 1987 and 1988 temperature profiles for sites 6C and 4C in Figure $9)$. We are highly confident of the following interpretations. The 1987 and 1988 drill holes at sites 2C(1980) and $3 \mathrm{C}(1980)$ were stopped by a sediment layer of subglacial origin that was too thick for the drill to penetrate. This layer was located as much as $22 \mathrm{~m}$ above the bed that was revealed by 1980 and 1981 drilling at the same geographical locations. There was no evidence for this layer in 1980 or 1981 and it is inconceivable that its existence would have escaped notice.

In 1990 we attempted to use an impulse radar survey to map the geometry and extent of this internal structure.
About 45 soundings were taken but results were equivocal. Because the surveyed region is extensively crevassed, it is impossible to make a clear distinction between echoes from internal reflectors and echoes from surface crevasses.

Figure 12 shows several possible mechanisms for generating internal structures that could account for our drilling observations. The first mechanism (Fig. 12a-a') might be viewed as bulge formation within the deforming subglacial sediment. The second mechanism (Fig. 12b- $\mathrm{b}^{\prime}$ ) involves recumbent folding of subglacial sediment. The remaining mechanisms involve several variants of thrust faulting (Dahlstrom, 1969; Davis, 1984, p. 284-85). The first of these is simple thrust faulting (Fig. 12c- $\mathrm{c}^{\prime}$ ) for which the fault displacement is constant along the fault plane and the fault plane intersects the glacier surface. Such a restriction on displacement is unnecessary and it is possible that the fault imbricates and cuts the surface as several fault planes splaying from a single fault surface (Fig. 12d$d^{\prime}$ ) or terminates internally as a blind thrust that does not intersect the surface (Fig. 12e-e'). In the latter case, fault displacement varies along the fault surface reaching zero at the propagating edge of the fault surface, and the variation
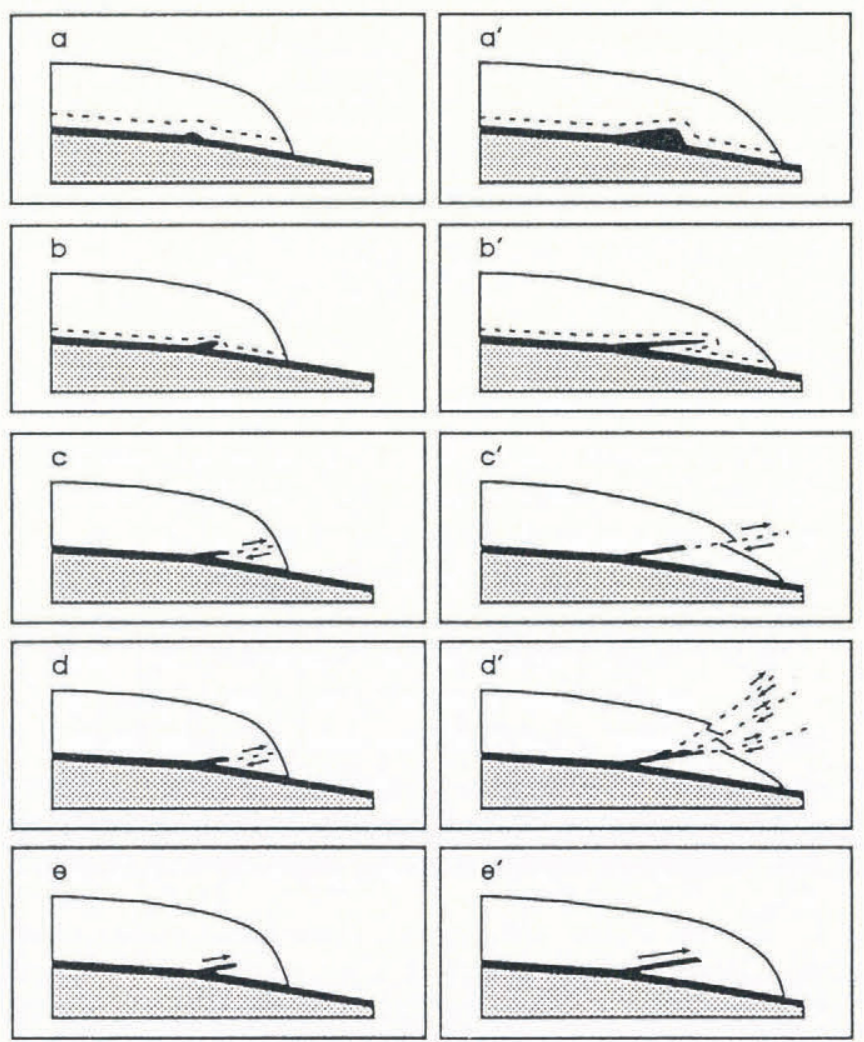

Fig. 12. Schematic diagram showing several candidate mechanisms for generating an internal layer of basal sediment. $\left(a-a^{\prime}\right)$ Formation of a sediment structure by bulge formation in the glacier substrate. $\left(b-b^{\prime}\right)$ Formation of an internal sediment structure by recumbent folding of glacier substrate. $\left(c-c^{\prime}\right)$ Formation of an internal sediment structure by simple thrust faulting of glacier substrate. $\left(d-d^{\prime}\right)$ Formation of an internal sediment structure by thrust faulting of glacier substrate but with the main thrust degenerating into numerous splay thrusts. $\left(e-e^{\prime}\right)$ Formation of an internal sediment structure by a blind thrust fault having inconsistent displacement. The fault plane terminates as an edge dislocation and the varying fault displacement is accommodated by creep deformation in the overthrusted block. 
in displacement is accommodated by creep deformation. This is our preferred mechanism for generating the proposed internal structure. The mechanisms we consider least likely are the bulging and simple thrust fault mechanisms. Bulge growth would require more subglacial sediment than is likely to be available to form the structure. Simple thrust faulting would require the existence of a fault plane along which there has been at least $100 \mathrm{~m}$ of thrust displacement (judging from Figure $9 \mathrm{c}$ and d). Such a fault should have an unmistakable surface expression, yet we have seen no evidence for it. It is possible that the total displacement is distributed over a large number of splay faults which we have failed to recognize because of extensive crevassing near the bulge, but we think it more probable that no thrust faults emerge from the glacier surface. The recumbent fold mechanism or the blind thrust-fault mechanism could generate the internal sediment structure without producing a surface fault plane. A difficulty with the recumbent-fold mechanism is that it implies extremely tight folding of ice in the immediate vicinity of the bed sediment structure. For this reason, we favour the final explanation, that a thrust plane exists but the fault terminates within the glacier.

The ice margin of Barnes Ice Cap (Hooke, 1973) and of Taylor Glacier (Shaw, 1977) inspired classic studies of glaciers that appear to have advanced over and incorporated their frontal aprons. When the apron is debris-rich, this process could result in a debris-rich layer of basal ice that could stop the progress of a hot-water drill. There is no possibility that the Trapridge Glacier internal structure can be explained in this fashion. The frontal apron of Trapridge Glacier was comparatively free of debris and apron ice appears to have been incorporated into the bulge front rather than being overridden by it (Figs 6 and 7).

\section{DISCUSSION}

The geomorphic effects of a transition from warm-based to cold-based ice have intrigued many investigators. Weertman (1961) discussed the genesis of Thule-Baffin moraines and challenged the prevailing view that: " 'Active' ice from the interior of an ice sheet moves outward to the edge where it is blocked by a zone of 'dead' ice. The active ice rides over the dead ice by slippage over active shear planes. It is further assumed that these active shear planes extend to the bottom of the ice sheet and that debris from the bed can be scraped up, carried into the ice to form debris layers, and ultimately be transported to the upper surface along these planes." His own proposal was that basal debris was incorporated by a freeze-on process operating in the thermal transition region. The recent history of Trapridge Glacier has involved ice thickening and a decrease in basal temperature gradients, trends that work against bottom freezing. If sediment freeze-on has been significant beneath Trapridge Glacier, the most favourable conditions occur in the post-surge receiving area when ice is thinning and bottom temperature is decreasing with time.

Hutter and Olunloyo $(1980,1981)$ considered an idealized case where there was an abrupt spatial transition from a region of basal sliding (corresponding to a warmbased glacier) to a region of adherence (corresponding to a
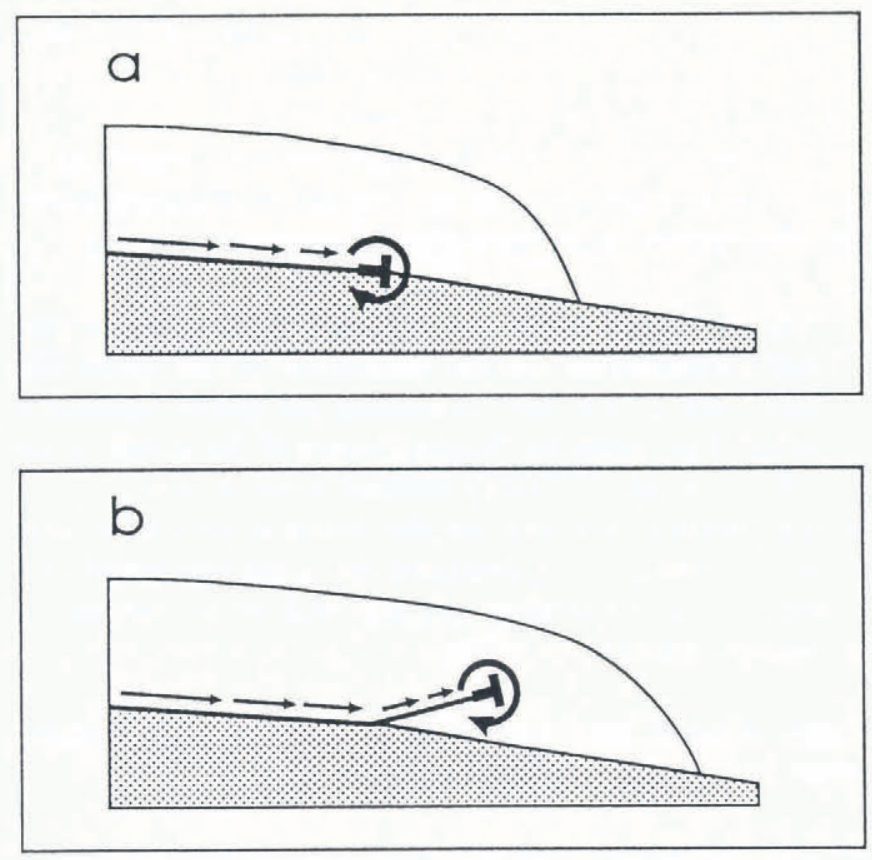

Fig. 13. Propagation of a Hutter-Olunloyo-type stress singularity as a migrating edge dislocation. The encircled " $T$ " symbol denotes a stress singularity and an associated discontinuity in the strain-rate field that is analogous to an edge dislocation. Note that the sliding rate (indicated by arrows of varying length) decreases as the singularity is approached from the upstream direction. (a) Transition from a sliding to an adhering boundary condition caused, in the case of Trapridge Glacier, by the transition from warm- to coldbedded ice. (b) Englacial migration of the sliding to nonsliding transition, creating a blind thrust. The resulting fault plane terminates within the glacier and does not intersect the upper surface.

cold-based glacier).* They discovered that this situation gives rise to a mathematical singularity in basal stress, and went on to speculate that such a stress singularity might favour erosion of the subglacial bed. Our structural interpretations suggest that regions of concentrated stress, such as those analyzed in the Hutter-Olunloyo theory are capable of migrating and, in fact, are not constrained to migrate along the ice-bed boundary, but can launch upward from the bed. In many respects the stresses and strain rates that appear to be involved resemble the stresses and strains associated with edge dislocations in elastic media (Steketee, 1958a, b; Chinnery, 1961). The rich literature on moving edge dislocations (e.g. Hirth and Lothe, 1968 , p. 163-69) may provide a departure point from which a more complete version of the HutterOlunloyo theory can be constructed. Figure 13 illustrates the englacial migration of a stress singularity and shows the displacement discontinuity that would result. The magnitude of the displacement discontinuity (corresponding to the Burgers' vector in dislocation theory) vanishes at the position of the singularity line and increases with distance

*In the course of editing this manuscript $\mathrm{K}$. Hutter drew our attention to an important paper by Richardson (1970) that presents an exact solution to the problem addressed by Hutter and Olunloyo. 
away from it. Unlike the elastic case, the deformation that accommodates the variable displacement discontinuity is non-recoverable and caused by creep.

We cannot conclude this paper without returning to the question of glacier surging. It is worthwhile summarizing observations that constrain the surge mechanism:

1. The cold-based apron or "ice dam" (Collins, 1972) may have contributed to the formation of the wave-like bulge but it was not buttressing the glacier against a surge. The complete disappearance of the apron, since 1988, has not noticeably affected ice-flow rates.

2. The glacier has exactly the thermal structure that would encourage speculation on a thermal instability mechanism controlling surging, but we see no strong case for thermal instability.

From separate hydrological studies (Stone and Clarke, 1989) we can add the following observations:

3. The cold-based zone does not prevent the outflow of basal water although it may complicate the process of establishing a water-exit system by forcing water to drain laterally to ice-marginal streams or tunnel, in some fashion, through or beneath the cold-based zone.

4. Subglacial water upstream from the cold-based zone is not ponded, at least not throughout the entire year.

In our opinion the results presented in this paper lend no support to surge mechanisms that rely on the presence of thermal or mechanical dams even though both are found at Trapridge Glacier.

\section{ACKNOWLEDGEMENTS}

This research was enabled by grants from the Natural Sciences and Engineering Research Council of Canada and by student support grants from the Northern Scientific Training Program of the Department of Indian Affairs and Northern Development of Canada and from the Canadian Northern Studies Trust of the Association of Canadian Universities for Northern Studies. We thank Parks Canada for permission to conduct this research in a national park and we especially thank the Superindentent and staff of Kluane National Park for their co-operation and interest. The Heritage Branch of the Government of the Yukon Territory licenses our Yukon field work. Our field study would never have been started and could not continue without the logistic support of Kluane Lake Research Station, owned and operated by the Arctic Institute of North America, University of Calgary. In particular, we thank A. Williams and G. Thompson of the Arctic Institute for their success in keeping the Kluane Lake Research Station operating through some difficult years.

Many individuals contributed to the data collection upon which this paper is based. We thank them all, but offer special thanks to S. G. Collins and M. C. Gérin who directed most of the surveys upon which our geometric results are based, to J. Shaw and C. C. Smart who raised the quality of our science, and to B. B. Narod who carried out the 1990 radar survey. R. P. Sharp and W. A. Wood kindly made their pre-surge photographs available to us.

\section{REFERENCES}

Bindschadler, R., W.D. Harrison, C.F. Raymond and R. S. Crosson. 1977. Geometry and dynamics of a surgetype glacier. 7. Glaciol., 18(79): 181-194.

Blake, E.W. and G. K.C. Clarke, 1988. Subglacial electrical phenomena. EOS, 59(44), 1211. [Abstract.]

Blake, E. W. and G. K. C. Clarke. 1989. In situ bed strain measurements beneath a surge-type glacier. EOS, 70(43), 1084. [Abstract.]

Blake, E. W., G. K. C. Clarke and M. C. Gérin. 1991. Tools for examining subglacial bed deformation. 7. Glaciol.

Blatter, H. 1987. On the thermal regime of an Arctic valley glacier: a study of White Glacier, Axel Heiberg Island, N.W.T., Canada. J. Glaciol., 33(114), 200-211.

Chinnery, M.A. 1961. The deformation of the ground around surface faults. Bull. Seismol. Soc. Am., 51(3), 355372.

Clarke, G.K.C. 1976. Thermal regulation of glacier surging. 7. Glaciol., 16(74), 231-250.

Clarke, G.K. C. 1987. Subglacial till: a physical framework for its properties and processes. F. Geophys. Res., 92(B9), 9023-9036.

Clarke, G. K. C. and E. W. Blake. 1990. Temporal changes in subglacial acoustic properties. EOS, 71(43), 1314 1315.

Clarke, G. K. C. and M. C. Gérin. 1989. Presurge fluctuations in water pressure and velocity, Trapridge Glacier, Yukon Territory. EOS, 70(43), 1084. [Abstract.]

Clarke, G. K. C., S. G. Collins and D. E. Thompson. 1984. Flow, thermal structure, and subglacial conditions of a surge-type glacier. Can. J. Earth Sci., 21(2), 232-240.

Clarke, G. K. C., U. Nitsan and W. S. B. Paterson. 1977. Strain heating and creep instability in glaciers and ice sheets. Rev. Geophys. Space Phys., 15(2), 235-247.

Collins, S. G. 1972. Survey of the Rusty Glacier area, Yukon Territory, Canada, 1967-70. J. Glaciol., 11(62), 235-253.

Dahlstrom, C. D. A. 1969. Balanced cross sections. Can. J. Earth Sci., 6(4), 743-757.

Davis, G. H. 1984. Structural geology of rocks and regions. New York, John Wiley and Sons.

Hirth, J. P. and J. Lothe. 1968. Theory of dislocations. New York, McGraw-Hill Book Company.

Hooke, R. L. 1973. Flow near the margin of the Barnes Ice Cap, and the development of ice-cored moraine. Geol. Soc. Am. Bull., 84(12), 3929-3948.

Humphrey, N., C. F. Raymond and W. D. Harrison. 1986. Discharges of turbid water during mini-surges of Variegated Glacier, Alaska, U.S.A. J. Glaciol., 32(111), 195-207.

Hutter, K. and V.O. S. Olunloyo. 1980. On the distribution of stress and velocity in an ice strip, which is partly sliding over and partly adhering to its bed using a Newtonian viscous approximation. Proc. Roy. Soc. London, A373, 385-403.

Hutter, K. and V.O.S. Olunloyo. 1981. Basal stress concentrations due to abrupt changes in boundary conditions. A cause for high till concentration at the bottom of a glacier. Ann. Glaciol., 2, 29-33.

Hutter, K., H. Blatter and M. Funk, 1988. A model computation of moisture content in polythermal glaciers. 7. Geophys. Res., 93(B10), 12205-12214. 
Jarvis, J.T. and G.K.C. Clarke. 1975. The thermal regime of Trapridge Glacier and its relevance to glacier surging. F. Glaciol., 14(71), 235-250.

Kamb, W.B. 1987. Glacier surge mechanism based on linked cavity configuration of the basal water conduit system. 7. Geophys. Res., 92(B9), 9083-9100.

Kamb, W. B. and H. Engelhardt. 1987. Waves of accelerated motion in a glacier approaching surge: The mini-surges of Variegated Glacier, Alaska, f. Glaciol., 33(113), 27-46.

Kamb, W.B., C.F. Raymond, W.D. Harrison, H. Engelhardt, K. A. Echelmeyer, N. Humphrey, M. M. Brugman and T. Pfeffer. 1985. Glacier surge mechanism: 1982-1983 surge of Variegated Glacier, Alaska. Science, 227(4686), 469-479.

Meier, M. F. and A. S. Post. 1969. What are glacier surges? Can. 7. Earth Sci., 6(4), 807-817.

Raymond, C.F., and W. D. Harrison. 1988. Evolution of Variegated Glacier, Alaska, U.S.A., prior to its surge. $\mathcal{F}$. Glaciol., 34(117), 154-169.

Raymond, C. F. and S. Malone, 1986. Propagating strain anomalies during mini-surges of Variegated Glacier, Alaska, U.S.A. J. Glaciol., 32(111), 178-191.

Richardson, S. 1970. A 'stick-slip' problem related to the motion of a free jet at low Reynolds number. Proc. Camb. Phil. Soc., 67(2), 477-489.

Schytt, V, 1969. Some comments on glacier surges in eastern Svalbard. Can. J. Earth Sci., 6(4), 867-873.

Sharp, R. P. 1947. The Wolf Creek glaciers, St. Elias Range, Yukon Territory. Geog. Rev., 37(1), 26-52.
Sharp, R.P. 1951. The glacial history of Wolf Creek, St. Elias Range, Canada. 7. Geol., 59(2), 97-117.

Shaw, J. 1977. Till body morphology and structure related to glacier flow. Boreas, 6, 189-201.

Smart, C. C. and G. K. C. Clarke. 1988. Basal hydrology of a surge-type glacier. EOS, 59(44), 1210-1211. [Abstract.]

Steketee, J. A. 1958a. On Volterra's dislocations in a semiinfinite elastic medium. Can. J. Phys., 36(2), 192-205.

Steketee, J. A. 1958b. Some geophysical applications of the elasticity theory of dislocations. Can. F. Phys., 36(9), 1168-1198.

Stone, D. B. and G. K. C. Clarke. 1989. Subglacial turbidity and and water pressure variations beneath Trapridge Glacier, Yukon Territory. EOS, 70(43), 1084. [Abstract.]

Weertman, J. 1961. Mechanism for the formation of inner moraines found near the edge of cold ice caps and ice sheets. F. Glaciol., 3(30), 965-978.

Wood, F. H. 1940. An attempt on Mt. Wood, St. Elias Range. Am. Alpine F., 4(1), 1-8.

Wood, W. A. 1936. The Wood Yukon expedition of 1935 : an experiment in photographic mapping. Geog. Rev., 26(2), 228-246.

Wood, W.A. 1942. The parachuting of expedition supplies. Geog. Rev., 32(1), 36-55.

The accuracy of references in the text and in this list is the responsibility of the authors, to whom queries should be addressed. 